\title{
A Review of Some Agricultural Wastes in Nigeria for Sustainability in the Production of Structural Concrete
}

\author{
C. Fapohunda*, A. Kilani, B. Adigo, L. Ajayi, B. Famodimu, O. Oladipupo, A. Jeje \\ Department of Civil Engineering, Federal University Oye-Ekiti, Nigeria.
}

ABSTRACT: A review of agricultural wastes available in Nigeria that is suitable for use in concrete industry, in order to attain sustainability in structural concrete production and practice, is presented in this paper. The wastes reviewed are: Cassava Peel Ash (CPA), Empty Palm Oil Fruit Brunch Ash (EPO-FBA), Rice Husk Ash (RHA), and Saw Dust Ash (SDA). Others were Palm Kernel Shell Ash (PKSA), Groundnut Husk Ash (GHA), Corncob Ash (CA), and Egg Shell Powder (ESP). The study revealed that some agricultural wastes that have potential for use as supplementary cementing material (SCM) for cement in the production of structural concrete abounds in Nigeria. It was also revealed that the necessity of standardization of procedures for testing of such wastes so that structural performance index can be compared. In addition, there is also the need for the development of classification methods similar to that of fly ash, so that their use can be enhanced. Using these waste materials in concrete will lead to sustainability in concrete production, reduction in the use of natural non-renewable resources, innovativeness in the use of wastes, and the development of small-scale industries.

KEYWORDS: Agricultural waste, Compressive strength, Pozzolans, Structure, Sustainability.

[Received Jan. 13, 2021; Revised April 6, 2021; Accepted June 2, 2021]

Print ISSN: 0189-9546 | Online ISSN: 2437-2110

\section{INTRODUCTION}

Structural Engineering, a creative process of finding a safe, durable and economic solution to infrastructural problems, has in recent times, widens its scope to include environmental issues (Fapohunda, 2019 and Brito and Kurda, 2021). This is because its practice, which involves usage of non-renewable natural resources on a very huge scale, has a very large environmental footprint (Bauma, 2019). Concrete, the most widely used structural material is produced using cement, sand, gravel and water. The production of cement not only requires massive use of limestone, a non-renewable natural resource, but also results in the release of $\mathrm{CO}_{2}$ and other greenhouse gases (GHGs) into the atmosphere (Naik and Moriconi, 2008). According to Mehta (2002) and Sudendro (2014), the contribution of cement industry to global emission of greenhouse gases is between 8 to $10 \%$. It is also the third most energy-intensive industry (Shafigh et al., 2014). The gravel components of the concrete are obtained from quarry operations involving the blasting of rock deposits, while sand deposits and river beds serve as the source of sand.

These natural resources are non-renewable, and so, the use of these materials for the production of structural concrete raises serious sustainability issues in the sense of meeting the present needs in the way that undermines the ability of future generations to meet their own needs. Structural engineers around the world are confronting these problems through innovative use of industrial and agricultural wastes materials, making them fit for use, mostly as partial replacement of one of the concrete components (Ochsendorf, 2005, Sunhenro,
2014, and Fapohunda, 2019). It is the view of Mehta (2002 \& 2009 ) that major reduction in the $\mathrm{CO}_{2}$ emission associated with cement production can be achieved by lowering the clinker content of the final product through maximization of the proportion of mineral admixtures in cement, and increase in the use of blended cements in general construction. It has further been shown that if just $30 \%$ of cement used globally was replaced with Supplementary Cementing Materials ( $\mathrm{SCMs}$ ), the rise in $\mathrm{CO}_{2}$ emissions from cement production could be reversed (Ecosmart, 2008).

Although, Nigeria may not boast of many industrial wastes like silica fume, ground granulated blast furnace slag, fly ash, etc., agricultural wastes abound from which materials for structural concrete can be obtained. These agricultural wastes are presently improperly disposed of, resulting in environmental pollution and nuisance. A polluted environment is hazardous to human's health. Researchers from all the nations of the world have investigated many of these wastes for structural potentials with promising results. Thus, the aim of this research is to review research works on some of the agricultural wastes available in Nigeria in relation to their fitness for use as Supplementing Cementing Materials (SCM) for cement in the production of structural concrete. The reviewed agricultural wastes in the present work are: Cassava Peel Ash (CPA), Empty Palm Oil Fruit Brunch Ash (EPOFBA), Rice Husk Ash (RHA) and Saw Dust Ash (SDA). Others mentioned are: Corncob Ash (CA), Egg Shell Powder (ESP), Groundnut Husk Ash (GHA), and Palm Kernel Shell Ash (PKSA) 


\section{AGRICULTURAL WASTES FOR THE PRODUCTION OF STRUCTURAL CONCRETE}

\section{A. Cassava Peel Ash (CPA)}

Cassava Peel Ash (CPA) is obtained by calcination of cassava peel, which is a by-product of cassava processing, either for domestic consumption or industrial uses. For the ash to be pozzolanic, Ikponmwosa and Olonade (2017) suggested the calcination of the cassava peel at $700^{\circ} \mathrm{C}$ for 90 minutes, so that the combined silica, alumina and ferric oxide in the ash are more than 70 per cent. Adesanya et al. (2008) reported that cassava peel constitutes between $20-35 \%$ of the weight of tuber, especially in the case of hand peeling. He further reported that about 6.8 million tons of cassava peel is generated annually, which a projection to reach 12 million tons by the year 2020 .
Although some of these wastes are being used as livestock feeds, for briquettes, etc., the majority of the waste are not used, and are disposed of indiscriminately. Indiscriminate disposal of cassava peels due to gross underutilization as well as lack of appropriate technology to recycle them is a major challenge, which results in environmental problem.

\section{1) Physical and chemical properties}

The specific gravity of CPA, according to Amartey et al. (2017) is 2.32 as against 3.04 for ordinary Portland cement (OPC) that it is meant to replace. What this means is that more CPA is needed for a unit weight replacement of cement with CPA. The chemical properties of CPA are shown in Table 1.

Table 1: Chemical properties of CPA.

\begin{tabular}{|c|c|c|c|c|c|c|c|c|c|}
\hline \multirow[t]{2}{*}{ Material } & \multicolumn{9}{|c|}{ Oxide (\%) } \\
\hline & $\mathrm{SiO}_{2}$ & $\mathrm{Al}_{2} \mathrm{O}_{3}$ & $\mathrm{Fe}_{2} \mathrm{O}_{3}$ & $\mathrm{CaO}$ & $\mathrm{MgO}$ & $\mathrm{Na}_{2} \mathrm{O}$ & $\mathrm{K}_{2} \mathrm{O}$ & $\mathrm{SO}_{3}$ & LOI \\
\hline Cement & 20.80 & 3.10 & 2.50 & 64.50 & 1.70 & 0.23 & 0.85 & 2.50 & 3.40 \\
\hline CPA & 36.79 & 7.57 & 2.23 & 8.20 & 2.90 & 1.37 & 18.74 & 1.52 & 15.10 \\
\hline
\end{tabular}

Source: (Ikponmwosa and Olonade, 2017).

It can be observed that the dominant oxide in CPA is the silicates $\left(\mathrm{SiO}_{2}\right)$ which is the major contributor to the binding properties of cement during hydration processes in the presence of water. According to Neville (2011), the silicates are the main cementitious compounds and the behavior of cement during hydration is similar to the behavior of the silicates.

\section{2) Fresh state properties}

The results of investigation conducted by Salau et al. (2012) showed that the water required to achieve standard consistency in cement-CPA paste increased with CPA content. Further, Salau et al. (2012) also found out that the slump values decreased with increase in amount of CPA for thesame water- binder ratio. This indicates that more water is required to maintain the same consistency as the CPA content increases.

\section{3) Hardened state properties}

Salau et al. (2012) concluded that using CPA as replacement of cement up to $25 \%$ by weight will result in densities range between 2414 and $2473 \mathrm{~kg} / \mathrm{m}^{3}$ indicating that they can be categorized as normal concrete with density of $2400 \mathrm{~kg} / \mathrm{m}^{3}$ (Table 2). They also showed that up to $15 \%$ replacement levels, the compressive strength of concrete specimens with CPA is comparable to specimens without CPA (Table 2). The strength activation index (SAI) specimens at replacement levels up to $15 \%$ developed compressive strength (CS) that is more than that of $75 \%$ of the control as per ASTM

Table 2: Density, compressive strength and strength activation index of specimens with CPA.

\begin{tabular}{|c|c|c|c|c|c|c|c|c|c|c|c|c|c|c|c|}
\hline \multirow{3}{*}{$\begin{array}{c}\% \\
\text { CPA }\end{array}$} & \multirow{2}{*}{\multicolumn{5}{|c|}{$\begin{array}{c}\text { Density }\left(\mathrm{kg} / \mathrm{m}^{3}\right) \\
\text { Curing ages (Days) }\end{array}$}} & \multicolumn{10}{|c|}{ Curing Ages (Days) } \\
\hline & & & & & & \multicolumn{2}{|c|}{7} & \multicolumn{2}{|c|}{28} & \multicolumn{2}{|c|}{56} & \multicolumn{2}{|c|}{90} & \multicolumn{2}{|c|}{120} \\
\hline & 7 & 28 & 56 & 90 & 120 & CS & SAI & CS & SAI & $\mathbf{C S}$ & SAI & CS & SAI & CS & SAI \\
\hline 0 & 2414 & 2414 & 2427 & 2483 & 2469 & 16.6 & 100 & 18.7 & 100 & 20.3 & 100 & 21.9 & 100 & 22.3 & 100 \\
\hline 5 & 2456 & 2405 & 2423 & 2421 & 2468 & 11.9 & 72 & 15.6 & 83 & 18.6 & 91 & 21.0 & 96 & 22.2 & 99 \\
\hline 10 & 2427 & 2452 & 2473 & 2417 & 2427 & 11.4 & 68 & 15.3 & 82 & 17.9 & 88 & 19.8 & 90 & 21.2 & 95 \\
\hline 15 & 2420 & 2456 & 2441 & 2441 & 2436 & 10.6 & 84 & 14.7 & 79 & 17.2 & 85 & 18.7 & 85 & 19.4 & 87 \\
\hline 20 & 2425 & 2437 & 2431 & 2439 & 2431 & 9.6 & 58 & 12.8 & 68 & 14.3 & 70 & 16.3 & 74 & 16.6 & 74 \\
\hline 25 & 2438 & 2428 & 2421 & 2466 & 2425 & 9.2 & 56 & 12.5 & 67 & 13.9 & 69 & 15.6 & 71 & 16.2 & 72 \\
\hline
\end{tabular}

Source: (Salau et al. (2012)

Improvement in the compressive strength development was observed at later ages. This is characteristic of pozzolans. Further, they observed that the tensile strength followed the compressive strength pattern.

\section{4) Durability properties}

According to Ikponmwosa and Olonade (2017), Cassava peel ash reduces shrinkage of concrete, provided that the CPA

\section{618-08 (2005).}

content is kept below $15 \%$. However, the works of Olonade et al. (2014), showed that concrete with CPA will not perform well in sulphuric acid environment because of decrease in the compressive strength witnessed in their investigation.

\section{B. Empty Palm Oil Fruit Bunch Ash (EPO-FBA)}

The palm oil industry generates many wastes: the empty palm oil fruit bunch is one of them. This is the residue 
remaining, after the mesocarp and kernel of the palm fruit oil are removed (Figure 1).

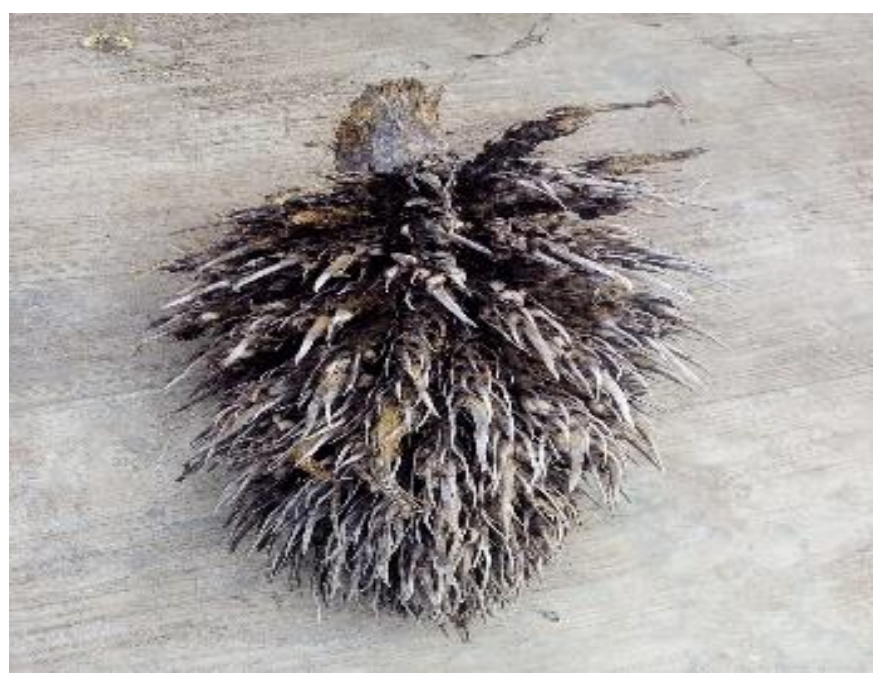

a) A Single empty fruit bunch.

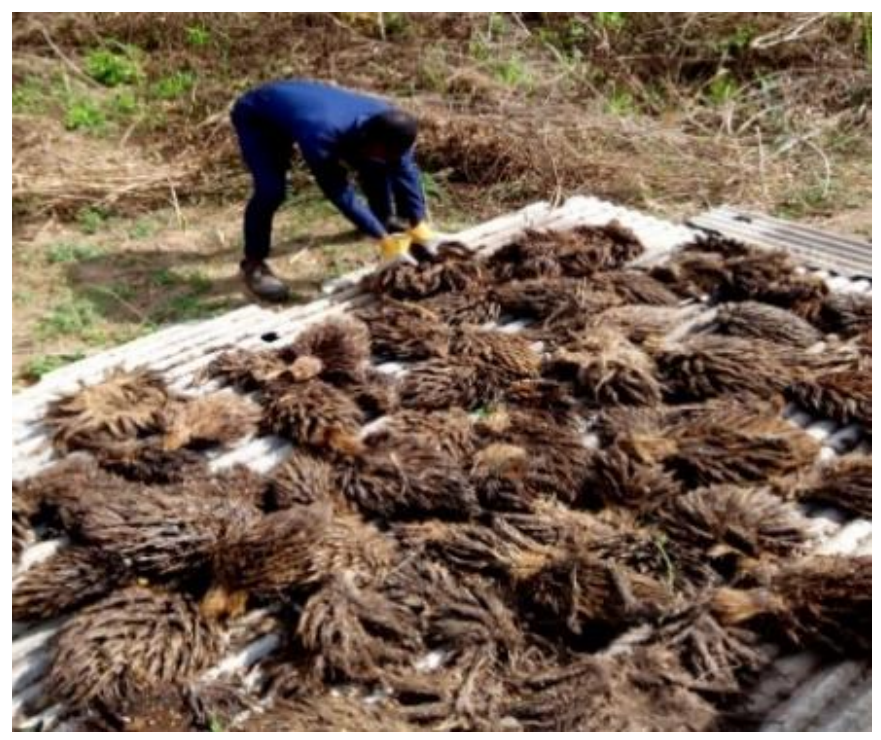

b) Drying of heap of empty fruit bunch.

Figure 1: Empty Palm Oil Fruit Bunch (Fapohunda and Oluwasegunota, 2019).

Its presence presently constitutes environmental nuisance, as no effective disposal method has been found (Fapohunda and Oluwasegunota, 2019). Thus, making it fit for usage in concrete production, will help in the protection of the environment by conserving the natural resources for cement, and also enable the civil/structural engineer affirm its commitment to sustainable practices in structural concrete. The Empty Palm Oil Fruit Brunch Ash (EPO-FBA), is the residue of burning empty palm oil fruit bunches through incineration process to $700^{\circ} \mathrm{C}$ within 90 minutes or open burning system (Coelho et al., 2019).

\section{1) Physical and Chemical Properties of EPO-FBA} In the result of fineness test carried on samples of EPO-FBA and Ordinary Portland Cement (OPC) by Fapohunda and Oluwasegunota (2019), percentage residue remained on the 90 $\mu \mathrm{m}$ sieve was found to be $9 \%$ for ordinary Portland cement (OPC) while that of EPO - FBA is $31 \%$. This indicated that EPO-FBA used is more coarse when compared with the OPC. The characterization as determined by Fapohunda and Oluwasegunota (2019) is presented in Table 3.

Table 3: Oxides Composition of Empty Palm Oil Fruit Bunch Ash (EPO-FBA).

\begin{tabular}{ccc}
\hline Oxides & EPO-FBA & OPC \\
\hline $\mathrm{CaO}(\%)$ & 19.01 & 64.37 \\
$\mathrm{SiO}_{2}(\%)$ & 6.42 & 20.68 \\
$\mathrm{Fe}_{2} \mathrm{O}_{3}(\%)$ & 6.64 & 3.62 \\
$\mathrm{MgO}(\%)$ & 4.10 & 1.81 \\
$\mathrm{Al}_{2} \mathrm{O}_{3}(\%)$ & 12.70 & 5.41 \\
$\mathrm{SO}_{3}(\%)$ & 1.42 & 1.03 \\
$\mathrm{Na}_{2} \mathrm{O}(\%)$ & 7.25 & 0.51 \\
$\mathrm{~K}_{2} \mathrm{O}(\%)$ & 1.86 & 0.47 \\
$\mathrm{LOI}(\%)$ & 40.60 & 0.39 \\
\hline
\end{tabular}

Source: (Fapohunda and Oluwasegunota, 2019)

From Table 3, it can be seen that the combined total of $\mathrm{SiO}_{2}+\mathrm{Al}_{2} \mathrm{O}_{3}+\mathrm{Fe}_{2} \mathrm{O}_{3}$, which is, $32.07 \%$, is not up to the value of above $50 \%$ that could permit classification into the categories of fly ash as per ASTM C 618 (2005). Also, the loss of ignition (LOI) present in the EPO-FBA is far greater than the LOI present in the cement. Neville (2011) was of the opinion that higher loss on ignition is advantageous since hydrated lime, which it reflected, is innocuous However, the chemical composition is similar to bauxite waste (found in Ghana) and natural cement (found in UK) recorded as pozzolans by Day (1990), as well as limestone powder (LSP) in the work of Le et al. (2014). This is because, hydrated free lime is innocuous, and for a given free lime content of cement, a greater loss on ignition is really advantageous (Neville (2011).

\section{2) Fresh state properties}

Findings by Fapohunda and Oluwasegunota (2019) showed that water content that will produce the desired consistency (expressed as a percentage by weight of the dry cement, usually between 26 and 33\%) of paste containing EPO-FBA increased with increase in the EPO-FBA content. These results indicated that more water will be required to obtain a consistent mix, when used in concrete. Unless high water cement-ratio is used, mix containing EPO-FBA may lead to harsh mix and hydration process may stop prematurely leading to reduced strength. The initial and final setting times of paste with and without EPO-FBA were also found to be within the limits set of 60 minutes prescribed by BS EN 197-1 (2000) for cement with strength $42.5 \mathrm{MPa}$. In addition, the slump values of concrete with EPO-FBA decrease to as low as $20 \mathrm{~mm}$ with increase in percent replacement of cement with EPO-FBA (Fapohunda and Shittu, 2017). The numerical slump value of $20 \mathrm{~mm}$ translates to concrete with low workability (Neville, 2011). Gambhir (2013) suggested that concrete with low workability, in the manner displayed by concrete specimens with EPO-FBA, can be employed in lightly reinforced structural concrete sections of slabs, beams, walls, column, strip footings with substructure walls, hand placed pavement and for mass concrete. 


\section{3) Hardened state properties}

Fapohunda and Oluwasegunota (2019) showed that the developed densities of the concrete specimens with EPO-FBA are between 2406 and $2510 \mathrm{~kg} / \mathrm{m}^{3}$.This suggests concrete containing EPO-FBA can be used for normal structural concrete applications. Using the performance criterium through Strength Activation Index (SAI), specimens with EPO-FBA up to $10 \%$ developed compressive strengths comparable to the control (ASTM C 618-08, 2005) at the 28day curing (Table 4).

Table 4: Potential of EPO-FBA as pozzolanic potentials of the samples.

\begin{tabular}{|c|c|c|c|c|c|c|c|c|c|c|}
\hline \multirow{4}{*}{$\begin{array}{c}\text { Mix } \\
\text { Designation }\end{array}$} & \multicolumn{10}{|c|}{ Compressive Strength, CS $\left(\mathrm{N} / \mathrm{mm}^{2}\right)$ and Strength Activation Index, SAI } \\
\hline & \multicolumn{10}{|c|}{ Curing Age (days) } \\
\hline & \multicolumn{2}{|c|}{7} & \multicolumn{2}{|c|}{14} & \multicolumn{2}{|c|}{28} & \multicolumn{2}{|c|}{60} & \multicolumn{2}{|c|}{90} \\
\hline & CS & SAI (\%) & CS & SAI (\%) & $\mathrm{CS}$ & SAI (\%) & CS & SAI (\%) & CS & SAI \\
\hline $\mathrm{M}_{0}$ & 24.84 & 100.00 & 25.34 & 100.00 & 29.78 & 100.00 & 33.61 & 100.00 & 35.28 & 100.00 \\
\hline $\mathrm{M}_{5}$ & 24.96 & 100.48 & 24.82 & 97.95 & 26.42 & 88.72 & 34.12 & 101.52 & 34.11 & 96.68 \\
\hline $\mathrm{M}_{10}$ & 19.82 & 79.79 & 22.71 & 89.62 & 24.38 & 81.87 & 30.75 & 91.49 & 32.90 & 93.25 \\
\hline $\mathrm{M}_{15}$ & 15.82 & 63.69 & 18.85 & 74.39 & 22.24 & 74.68 & 27.51 & 81.85 & 30.84 & 87.42 \\
\hline
\end{tabular}

Source: (Fapohunda and Oluwasegunota, 2019)

At higher curing ages of 60 and 90 days, all the specimens developed strength greater that $75 \%$ of the control. It can however be concluded that, on the basis of the SAI, the optimum use of EPO-FBA is at $10 \%$ replacement level.

\section{4) Durability properties}

The results of the investigation by Babatola (2018) to assess the durability properties showed a water absorption capacity of less than $10 \%$. This is an indication that concrete with EPOFBA will be durable. According to Nevile (2011), a good concrete should have a water absorption capacity of less than $10 \%$.

\section{Rice Husk Ash (RHA)}

Rice Husk Ash is obtained from calcination of Rice Husk, which is the by-product of rice milling operations, in riceproducing countries of the world. Approximately 1000 million tons of rice is annually produced in the world, which usually leaves about 400 million tons of rice husks as a waste material (IRRI, 2005). According to FINELIB (2019), Nigeria is the largest producer of rice in West Africa. FINELIB (2019) stated that rice is cultivated in states like Benue, Borno, Cross River, Enugu, Kaduna, Kano, Taraba, Niger, Kwara and Kebbi. Rice husk ash (RHA) can be produced either through open field burning (usually below $450^{\circ} \mathrm{C}$ ) or under incineration conditions in which temperature (in excess of $700^{\circ} \mathrm{C}$ ) and duration are controlled. However, open field calcination is not encouraged because of pollution problems and it also produces poor quality rice husk ash. It has been found out that the RHA produced from open burning has relatively high carbon content (above 4\%) which adversely affect concrete performance and also results in a structure of highly crystalline form that is of low reactivity (Hwang and Chandra, 2016). The RHA in the amorphous form of silica, which has the potential to be used for structural concrete, is produced through controlled incineration conditions (temperature and duration).

\section{1) Physical properties of RHA}

Some physical properties of Rice Husk Ash that are of structural relevance are the specific gravity, mean particle size, and its Blaine fineness. Investigations conducted by Chatveera and Lertwattanaruk (2009); Marthong (2012), and Karim et al. (2013) showed that the specific gravity of RHA varies between
$2.05-2.53$. These values are relatively lower than the specific gravity of the ordinary Portland cement which is between 3.10 and 3.14 (Ganesan et al., 2008; Tangchirapat et al., 2009) that it is meant to partially replace. What this means is that, for a unit weight replaced by cement, higher volume of RHA will be required. The consequence of this is that, the concrete produced will have a relatively lower density than the concrete without RHA. Lower density will result as the percent replacement increases (Obilade, 2014). In order for RHA to be used as a binder, majority of research studies conducted concluded that the material has to be ground into a very high specific surface area of up to $100 \mathrm{~m}^{2} / \mathrm{g}$ before use (Ganesan et al., 2008 and Nguyen et al., 2011). The investigation conducted by Antiohos et al. (2014) revealed that highest pozzolanic activities were achieved when the more reactive RHA was ground to $7000 \mathrm{~cm}^{2} / \mathrm{g}$. Also, for RHA to be pozzolanic, its particle size should be between $5.6-8 \mathrm{~mm}$ (Nguyen et al, 2011). The works of Bouzoubaa and Fournier (2001) revealed that median particle size of about $8 \mathrm{~mm}$ is required to achieve pozzolanic activity index of 100 percent.

\section{2) Oxides composition and pozzolanic properties}

The oxides composition of Rice Husk Ash (RHA) as obtained by various researchers (Joel 2010; Oyekan and Kamiyo 2011, Le et al., 2014 and Swaminathen and Ravi (2016)) showed a very high silica content - above $70 \%$. This is an indication of how reactive RHA is, since silica is the compound that has been found to be responsible for the strength in concrete (Nair et al., 2008). This is particularly good, for the high silica in RHA enables it to contribute to the strength development process if used in concrete production. Also, the sum of $\mathrm{SiO}_{2}+\mathrm{Al}_{2} \mathrm{O}_{3}+\mathrm{Fe}_{2} \mathrm{O}_{3}$ exceeds $70 \%$ for all the RHA specimens used by these researchers. This demonstrated that the RHA are in the same category with the Class F fly ash (ASTM C618-05, 2005) with high pozzolanic characteristics.

\section{3) Fresh state properties}

The fresh properties that are of significant in concrete production are, consistence, workability, and setting times. Consistence of concrete is the degree of wetness or otherwise which indicates whether a concrete is workable or not through the whole process of transportation, placement, finishing without segregation. Results of investigations conducted by Calica (2008), Kartini et al. (2010) and Marthong (2012) 
showed that paste containing RHA requires more water to achieve the standard consistence when compared to the samples without RHA. Water demand, according to Rashid (2016) increased with increase in cement replacement with RHA, and that it could be as high as $100 \%$. Also, the results of investigation conducted by Kartini et al., 2010 and Khassaf et al., 2014 on the effect of RHA on the workability of concrete showed a progressive reduction in workability as the percent replacement of cement with RHA increases unless waterreducing admixtures are used. There seems no agreement yet among researchers concerning the effect of RHA on the setting times of paste. The results of the investigation conducted by Oyetola and Abdullahi (2004), Dabai et al. (2009), Marthong (2012) showed both initial and final setting times increasing with increase in RHA irrespective of the grade of the ordinary Portland cement used. The work of Rashid et al. (2010) and Chanu and Devi (2013) however revealed different results. They found out that initial setting times increased up to $15 \%$ cement replacement and RHA. The obvious disagreement between these results was probably due to the fact that Rashid et al. (2010) used open burning method to obtain the RHA used, in which the burning temperature was less than $450^{\circ} \mathrm{C}$ within the time frame of 72 hours. This temperature will only produce crystalline RHA as has been previously discussed. It is possible that the setting times characteristics of crystalline RHA are different from that of amorphous RHA, and that this difference is yet to be well-understood.

\section{4) Hardened state properties}

The hardened state properties of concrete with RHA that researchers have come up with are: density, compressive strength, tensile strength, and modulus of elasticity. Results of investigations conducted by Adenuga et al. (2010) showed that the density of concrete specimens containing RHA decreased with increase in the content of RHA at all water-binder ratio. They also found out that the densities fell in the normal weight category of between $2200-2550 \mathrm{~kg} / \mathrm{m}^{3}$ as per ACI Committee 213 (2003) and Falade et al. (2011). This information is necessary to ensure effective application of RHA in concrete.

The results of some of these researchers showed that factors such as water-cement ratio and curing duration affect the compressive strength of concrete incorporating RHA. Chindaprasirta et al. (2009), and Babaiefar (2007) suggested that at the water cement ratios of $0.30,0.32$, and 0.34 compressive strength increased (relative to the control) with RHA up to $20 \%$ at the curing ranges between 7, 28 and 90 days. The works of Shatat (2014) and Mahmud et al., 2016) showed that concrete incorporating RHA developed later compressive strength that is higher than specimens without RHA (Figure 2). Investigations conducted by Le et al. (2014) and Foong et al. (2015) showed that the 28-day splitting tensile strength increased with increase in RHA contentup to $15 \%$ by as much as $17.65 \%$ and $28 \%$ respectively but decreased afterward to

about $5.88 \%$ ofthe control specimens at $20 \%$ replacement level of cement with RHA. However, the splitting tensile strength is about $10 \%$ of the compressive strength. Investigations conducted by Le et al. (2014) and Foong et al. (2015) showed that the 28-day splitting tensile strength increased with increase in RHA content up to $15 \%$ by as much as $17.65 \%$ and $28 \%$ respectively.

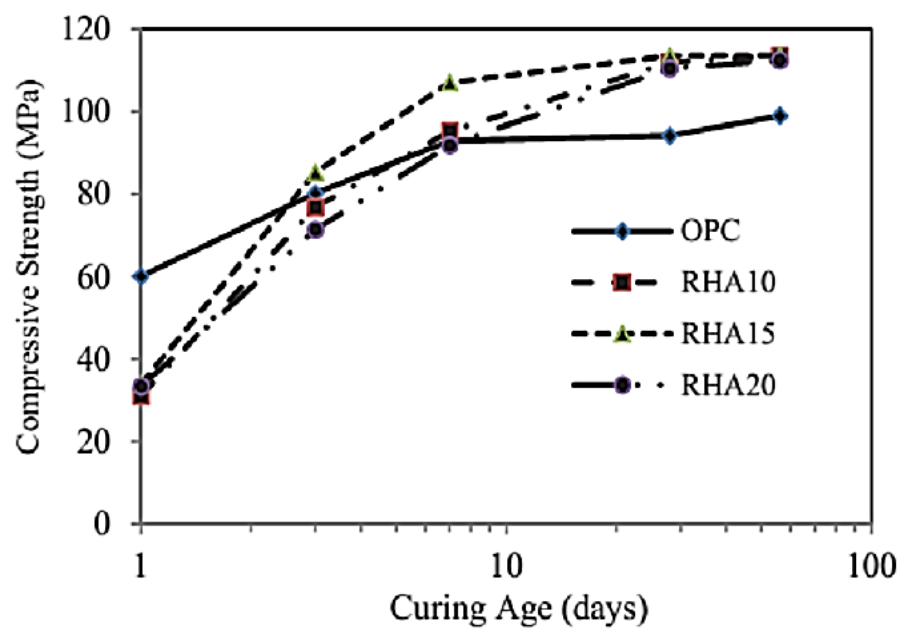

Figure 2: Effect of RHA on the compressive strength of concrete (Mahmud et al., 2016).

In addition, Foong et al. (2015, found out that it decreased afterward to about $5.88 \%$ of the control specimens at $20 \%$ replacement level of cement with RHA. However, the splitting tensile strength is about $10 \%$ of the compressive strength. There is also evidence that inclusion of RHA affect the modulus of rupture of concrete. Talsania et al. (2015) recorded an increase of up to $20 \%$ in the modulus of rupture when RHA was used in concrete. In a similar investigation, Foong et al. (2015) showed that the presence of RHA in concrete increased the Young's modulus by as much $25 \%$. In order to predict the Young Modulus of elasticity of concrete with RHA, Foong et al. (2015) further suggested Eq. (1).

$$
E=5\left(\frac{\rho}{2400}\right)^{2} f_{c u}^{0.333}
$$

where $E=$ Young modulus of elasticity (GPa), $\rho=$ density of concrete $\left(\mathrm{kg} / \mathrm{m}^{3}\right)$ and $f_{c u}=$ compressive (cube) strength $(\mathrm{MPa})$.

\section{5) Durability properties}

Importance of durability issues in structural design cannot be overemphasized, especially in limit state design, where the structure must not reach a state where it becomes unserviceable. The results of various researchers showed that RHA-concrete microstructure is impervious to agent of degradation like, sulphate attacks (Sakr, 2006), chloride ingress (Chopra et al., 2015); as well as good shrinkage properties (Khassaf et al., 2014). Its use in concrete also inhibit alkali-silicate reaction (Hasparyk et al., 2000) as well as lower water absorption and sorptivity (Da Silva et al., 2008).

\section{Sawdust Ash (SDA)}

Sawdust Ash (SDA) is produced when saw dust, which is a waste material from the sawmill industry, is thermally decomposed. According to Raheem et al. (2012) and Adamu 
et al. (2017), timber sawmills are located virtually in all major towns in Nigeria where sawdust is generated as waste daily.

\section{1) Physical and chemical properties}

The reported specific properties of SDA from structural perspectives include specific gravity, ranging from 2.05 to 2.60 and density ranging from $720-830 \mathrm{~kg} / \mathrm{m}^{3}$ (Udoeyo et al., 2006 and Ettu et al., 2013). When these values are compared with

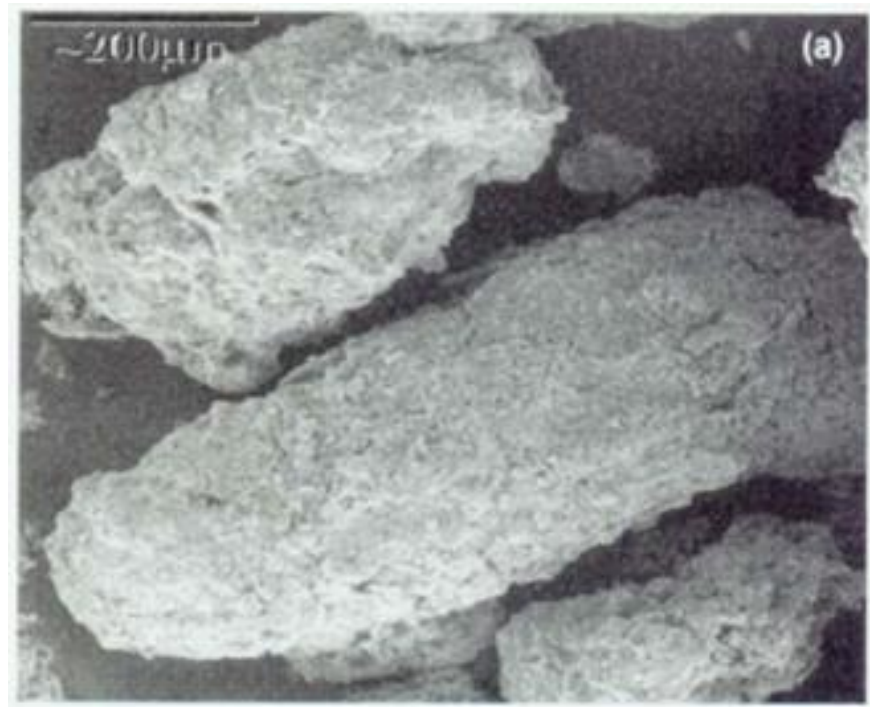

Figure 3: SEM micrographs of the structure of SDA.

Some of the wood ash particles were found to be porous (that is, in cellular form) agglomerated particles. These cellular particles are mostly unburnt or partially burnt wood chips, knots or bark particles. Further investigations by Naik and Kraus (2003), using X-ray diffraction (XRD) for the the ordinary Portland cement values - 3.12 specific gravity and $1550 \mathrm{~kg} / \mathrm{m}^{3}$ density - it is obvious that, for a unit weight of cement replaced with SDA, a larger volume will result and consequently lighter concrete (from weight-volume relations). Microstructural studies conducted by Naik and Kraus (2003) revealed that SEM micrographs showed wood ash as a heterogeneous mixture of particles of varying sizes that are generally angular in shapes (Figure 3).

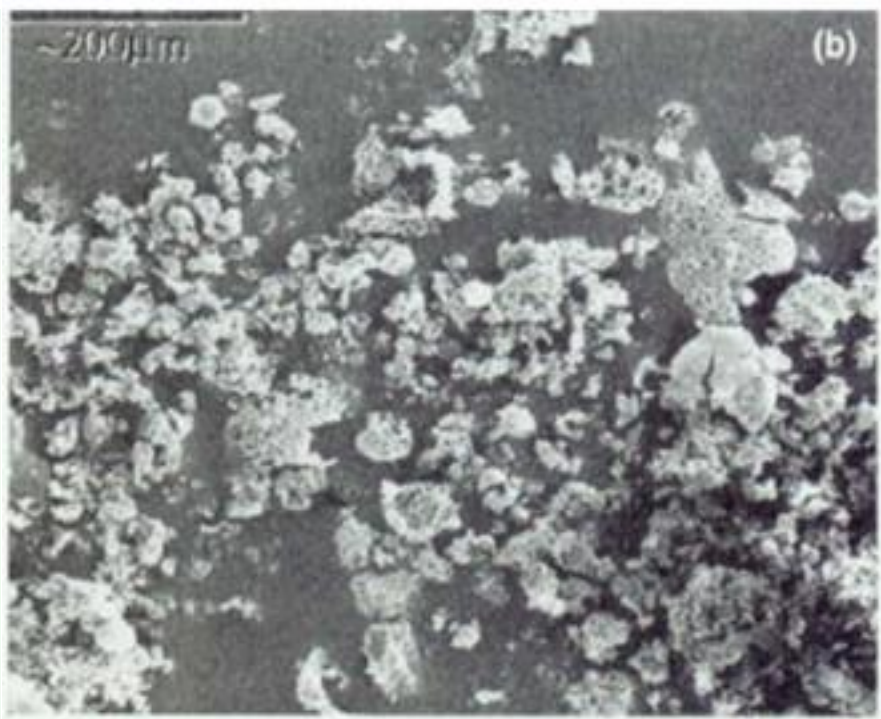

mineralogical analysis of wood ash, revealed that both amorphous (non-crystalline) and non-amorphous (crystalline) phases were present in the wood ash examined. The composition of oxides in sawdust ash, from the findings of Raheem et al. (2012) is presented Table 5.

Table 5: Oxides composition of SDA.

\begin{tabular}{ccccc}
\hline Oxide & \multicolumn{4}{c}{ Percentage composition (\%) } \\
\cline { 2 - 5 } & Sample 1 & Sample 2 & Sample 3 & Sample 4 \\
\hline $\mathrm{SiO}_{2}$ & 65.42 & 66.05 & 65.79 & 65.75 \\
$\mathrm{Al}_{2} \mathrm{O}_{3}$ & 5.69 & 5.12 & 4.88 & 5.23 \\
$\mathrm{Fe}_{2} \mathrm{O}_{3}$ & 2.16 & 2.09 & 2.01 & 2.09 \\
$\mathrm{CaO}$ & 9.82 & 9.65 & 9.39 & 9.62 \\
$\mathrm{MgO}$ & 4.23 & 4.11 & 3.03 & 4.09 \\
$\mathrm{SO}$ & 1.09 & 1.20 & 0.98 & 1.09 \\
$\mathrm{~K}_{2} \mathrm{O}$ & 2.38 & 2.22 & 2.68 & 2.43 \\
$\mathrm{Na} 2 \mathrm{O}$ & 0.04 & 0.08 & 0.07 & 0.06 \\
$\mathrm{LOI}$ & 4.89 & 4.05 & 3.95 & 4.30 \\
$\mathrm{LSF}$ & 1.09 & 1.98 & 2.07 & 1.71 \\
$\mathrm{SR}$ & 10.53 & 11.03 & 10.45 & 10.67 \\
$\mathrm{AR}$ & 11.35 & 12.88 & 12.73 & 12.32 \\
$\mathrm{Al}_{2} \mathrm{O}_{3}+\mathrm{Fe}_{2} \mathrm{O}_{3}$ & 73.27 & 73.26 & 72.78 & 73.07 \\
\hline
\end{tabular}

$\mathrm{LOI}=$ Loss on Ignition, $\mathrm{LSF}=$ Lime saturated factor, $\mathrm{SR}=$ Silica ratio, $\mathrm{AR}=$ Aluminum ratio

Source: (Raheem et al., 2012)

It can be seen that the sum of $\mathrm{SiO}_{2}+\mathrm{Al}_{2} \mathrm{O}_{3}+\mathrm{Fe}_{2} \mathrm{O}_{3}$ exceeds $70 \%$. This is an indication that sawdust ash is in the group with

Class F fly ash (ASTM C618-05, 2005), whose characteristics is high pozzolanicity.

\section{2) Fresh state properties}

Findings from various investigations by Elinwa and Ejeh (2004) and Abdullahi (2006) established that the inclusion of SDA as a partial cement replacement material in blended 
cement. resulted in a higher water requirement in order to achieve a standard level of cement paste consistency. The higher water demand of OPC-SDA paste relative to OPC is mainly due to a higher specific surface area of porous wood waste ash particles in comparison to OPC particles. The setting characteristics of paste containing SDA is shown in Figure 4.

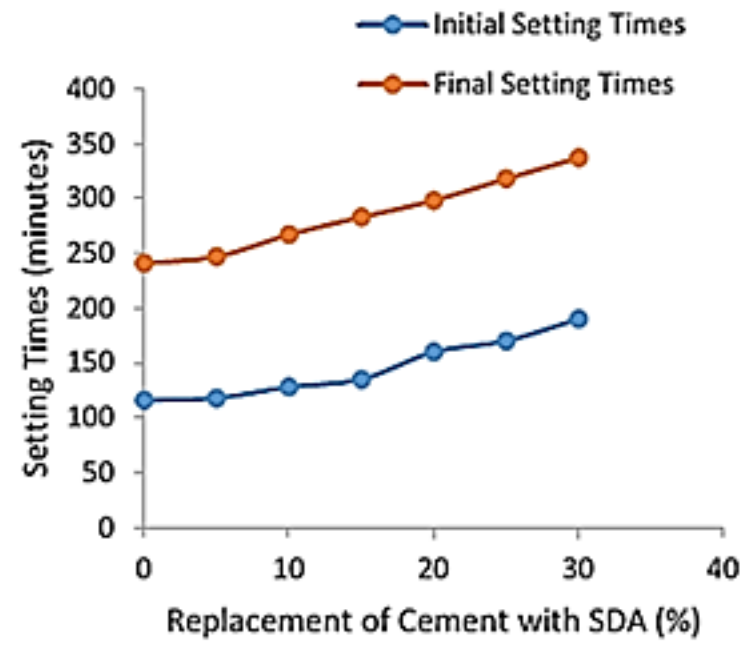

Figure 4: Initial and final setting times of paste with SDA (Elinwa \& Ejeh, 2004.).

It is observed in Figure 4 that both the initial and final setting times increased with increase in percent replacement of cement with SDA. This means that SDA acts as retarder. Also, the research conducted by Udoeyo et al. (2006) showed that concrete with SDA becomes less workable, turning into harsh mixes with increased content of SDA, and thus require higher water content to maintain its workability (Figure 5) (Elinwa and Mahmood (2002) and Udoeyo et al. (2006). Thus, using SDA will require appropriate dosage of super plasticizer in order maintain required workability.

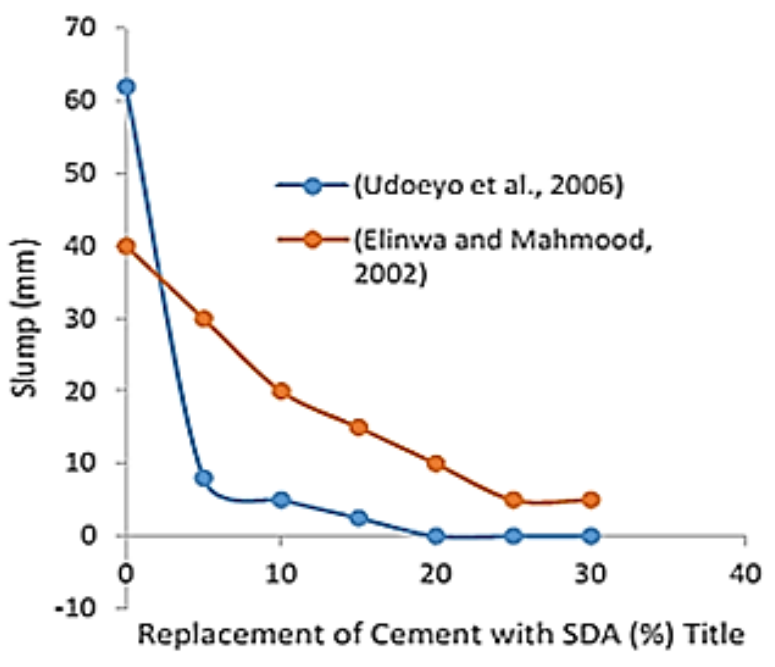

Figure 5: The slump characteristics of concrete with SDA.

\section{3) Hardened state properties}

The developed densities of specimens with SDA, from investigations conducted by researchers (Cheah and Ramli, 2012 and Ettu et al., 2013) were found to be in the range of range of 2220 and $2316 \mathrm{~kg} / \mathrm{m}^{3}$.for replacement values up to $40 \%$. These findings showed that SDA will develop densities that can be used for conventional normal weight applications.
The compressive strength, on the other hand decreased in relation to the control with increase in the percent replacement of cement with SDA (Udoeyo et al., 2006 and Raheem et al., 2012). However, the numerical values of compressive strength obtained from cube tests by researchers, as presented by Fapohunda et al. (2018) in Table 6, suggested that SDA can be incorporated into the concrete mixes to develop the required 
strength specified by various international standards. However, at the curing ages of 90 days, the results of Ghorpade
(2012) showed improved compressive strength over the control samples at replacement levels up to $30 \%$.

Table 6: The numerical values of compressive strength of concrete specimens with SDA.

\begin{tabular}{|c|c|c|c|c|c|}
\hline Authors & Mix & W/c ratio & $\begin{array}{l}\text { Max 28-day } \\
f_{c}\left(\mathbf{N} / \mathbf{m m}^{2}\right)\end{array}$ & Dosage (\%) & $\begin{array}{c}\text { Group } \\
\text { (Table 1) }\end{array}$ \\
\hline Chowdhury et al. (2015) & NA & $\begin{array}{l}0.40 \\
0.50\end{array}$ & $\begin{array}{l}31.70-35.30 \\
29.00-33.30\end{array}$ & $\begin{array}{l}5-20 \\
5-20\end{array}$ & $\mathrm{CaO}$ \\
\hline Marthong (2013) & NA & NA & 32.50 & Up to 10 & $\mathrm{SiO}_{2}$ \\
\hline Ogork and Ayuba (2014) & $1: 2: 4$ & 0.55 & 20.00 & Up to 10 & $\mathrm{CaO}$ \\
\hline Raheem et al. (2012) & $1: 2: 4$ & 0.60 & 15.00 & Up to 10 & $\mathrm{SiO}_{2}$ \\
\hline Subbaramaiah (2016) & 1: $1.84: 2.89$ & 0.50 & $24.00-39.74$ & Up to 40 & NA \\
\hline Ettu et al. (2013) & $1: 2: 4$ & 0.60 & 20.90 & Up to 10 & $\mathrm{SiO}_{2}$ \\
\hline Abhishek and Kumbar (2017) & 1: $1.61: 2.78$ & 0.45 & $25.00-36.00$ & Up to 15 & $\mathrm{CaO}$ \\
\hline Adamu et al. (2017) & $1: 2: 4$ & 0.55 & 22.00028 .00 & Up to 15 & $\mathrm{SiO}_{2}$ \\
\hline
\end{tabular}

Source: (Fapohunda et al., 2018)

Both the splitting tensile strength and the modulus of rupture decreased, in relation to the control, with increase in the percent cement replacement with SDA up to 28 days curing age (Udoeyo et al., 2006 and Rajamma et al., 2009). The developed tensile strength is between $9-10 \%$ of the compressive strength. There is however reason to believe that, beyond 28 days, the compressive strengths are higher than the control specimens (Naik et al., 2002).

\section{4) Durability properties}

Results of investigations suggested that concrete with SDA has good durability properties. For example, Udoeyo et al. (2006) obtained water absorption values of less than $10 \%$ for replacement up to $30 \%$. Neville (2011) considered concrete with absorption capacity less than $10 \%$ to be a good concrete. Similarly, Cheah and Ramli (2012) found out that specimens with SDA up to $15 \%$ developed shrinkage properties. Ramos et al. (2013) concluded that alkali-aggregate reaction is mitigated for replacement values up to $20 \%$. Cheah and Ramli (2012) observed reduced depth of carbonation (which is a measure of resistance to carbonation) in their investigation, suggesting ability to prevent carbonation. Reduced depth means improved carbonation resistance and vice versa. Wang et al. (2008) also showed that concrete containing SDA up to $25 \%$ exhibited improved chloride resistance. The results of Elinwa and Ejeh (2004) however suggested vulnerability of concrete with SDA in acidic environment

\section{IMPLICATIONS OF AGRICULTURAL WASTE IN CONCRETE PRODUCTION IN NIGERIA}

Relevant structural characteristics of some agricultural wastes have been presented in this review. Others that have been found to have pozzolanic potentials for structural use are: palm kernel shell ash - PKSA (Olutoge et al., 2012), groundnut husk ash - GHA (Ketkukah and Ndububa, 2006), corncob ash - CA (Adesanya et al., 2008), and egg shell powder - ESP (Yerramala, 2014). The optimum values vary between 10 to $30 \%$. However, there is the need for standardization of procedures for testing, knowing that the wastes perform differently. It is also necessary to classify these wastes in the way the American classified fly ash (ASTM C 618,2005 ), silica fume (ASTM C 1240, 2015) and granulated blast furnace slag (ASTM C 989, 2018). Standardization and classification will enhance the usage of these waste in structural concrete, and thus ensure following benefits:

i. Reduction in the Nigeria contribution to the total global emission of greenhouse gas

ii. Reduction in the consumption of non-renewable raw materials used in cement manufacture, thus helping to conserve the nation's natural resources.

iii. Help remove unwanted waste, resulting in a cleaner environment

iv. Development of small-scale industries around these wastes in the rural areas. This will provide employment opportunities for rural dwellers, improve GDP and reduce rural-urban migration.

v. Downward review of the price of cement will be occasioned by the total sum of these wastes, when they are available in the market as substitute to cement.

\section{CONCLUSION}

A review of some agricultural wastes that are found in Nigeria for possible use in the production of structural concrete is presented. From this review, it can be concluded that, in Nigeria abounds many wastes of agricultural origin that can be made fit for use as partial replacement of cement in the production of structural concrete. But standardization of tests and procedures of investigations as well as performance-based classification are not yet in place to enhance its usage. There are also some properties that are yet to be investigated such as: flexural responses, crack development, propagation and patterns, and shear behaviors of concrete with these agricultural wastes. All these are necessary for the complete structural response of these wastes to be captured. These are thus recommended for investigation. 


\section{REFERENCES}

Abdullahi, M. (2006). Characteristics of Wood ASH/OPC Concrete. Leonardo Electron J Pract. Technol, 8: 916.

Abhishek, D. S. and Kumbar, P. K. (2017). An experimental study on durability aspects of concrete with partial replacement of cement by sawdust ash. International Journal of Scientific Research Organization, 1(5): 36 - 41.

ACI Committee 213 (2003). Guide for Structural Lightweight Aggregate Concrete - ACI 213R-03, American Concrete Institute, Farmington Hills, MI.

Adamu, M.; A. S. Tifase, and O. A. U. Uche (2017). Engineering Properties of Industrial Wood Waste AshConcrete. International Journal of Advances in Construction Engineering, 1(1): $1-10$.

Adenuga, O. A.; Soyingbe, A. A. and Ogunsanmi, O. E. (2010). The Use of Rice Husk Ash as Partial Replacement for Cement in Concrete. The Lagos Journal of Environmental Studies, 7(2): 47-50.

Adesanya, O.A.; K. A. Oluyemi, S. J. Josiah, R. A. Adesanya, L. A. J. Shittu, D. A. Ofusori, M. A. Bankole and G. B. Babalola (2008). Ethanol Production by Saccharomyces Cereviasiae from cassava peel hydrolysate, The Internet Journal of Microbiology, 5(1): 25-35.

Antiohos, S. K.; V. G. Papadakis and S. Tsimas (2014). Rice Husk Ash (RSA) Effectiveness in Cement and Concrete as a Function of Reactive Silica and Fineness. Cement and Concrete Research, 61(62): $20-27$.

Amartey, Y. D.; J. K. Taku and B. H. Sada (2017). Optimization Model for Compressive Strength of Sandcrete Blocks Using Cassava Peel Ash (CPA) Blended Cement Mortar As Binder. Kathmandu University Journal of Sciences, Engineering and Technology, 13(2): 1-14.

ASTM C618-05 (2005). Standard Specification for Coal Fly Ash and Raw or Calcined Natural Pozzolan for Use as a Mineral Admixture in Concrete. American Society for Testing and Materials International, West Conshohocken Philadelphia.

ASTM C 989 (2018). Standard Specification for Slag Cement for Use in Concrete and Mortars. American Society for Testing and Materials International, West Conshohocken Philadelphia.

ASTM C 1240 (2015). Standard Specifications for Silica Fume Used in Cementitious Mixtures. American Society for Testing and Materials International, West Conshohocken Philadelphia.

Babaiefar, S. (2007). The Durability Assessment of Concrete made with Rice Husk Ash (RHA) in Sulphate Environment. Unpublished M.Sc. Thesis, Department of Civil Engineering, University of Guilan, Iran.

Babatola, A. (2018). Microstructure and Durability Performance of Concrete Containing Empty Palm Oil Fruit Brunch Ash (EPO-FBA) as partial Replacement of Ordinary Portland Cement (OPC). Unpublished BEng. Thesis, Department of Civil Engineering, Federal University, OyeEkiti, Nigeria.

Bauma (2019). Bauma 2019 - Sustainability is one of the Core Topics. ZKG International. Available on line at: http://www.zkg.de/en/news/bauma-20. Assessed November 5, 2020 .
Bouzoubaa, N., and Fournier, B. (2001). Concrete Incorporating Rice Husk Ash on Compressive Strength and Chloride Ion Penetrability, Materials Technology Laboratory. CANMET, Dept. of Natural Resources, Canada, $1-16$.

Brito, J. and Kunda, R. (2021). The past and future of sustainable concrete: A critical review and new strategies on cement-based materials. Journal of Cleaner Production, 21: 1 -220 .

BS EN 197-1 (2000). Cement, Composition, Specification and Conformity Criteria for Common Cements. British Standard Institution, London.

Calica Jr, M. G. (2008). Influence of Rice Husk Ash as Supplementary Material in Cement Paste and Concrete. NLR Journal, 2, 80-92. Available online at: http://pejard.slu.edu.ph /images /pdf/vol2/influence-of-rice-husk-ash-assupplementary-material-in-cement-paste-andconcrete.pdf. Accessed on October 10, 2020.

Chanu, N. M. and Devi, T. K. (2013). Contribution of Rice Husk Ash to the Properties of Cement Mortar and Concrete. International Journal of Engineering Research \& Technology, 2(2): 1-7.

Chatveera, B. and Lertwattanaruk, P. (2009). Evaluation of Sulfate Resistance of Cement Mortars Containing Black Rice Husk Ash. Journal of Environmental Management, 90(3): 1435-1441.

Cheah, C. B, and Ramli, M. (2012). Mechanical strength, durability and drying shrinkage of structural mortar containing HCWA as partial replacement of cement. Construction and Building Materials, 30: 320-329.

Chindaprasirt, P.; C. JatarapitaKul, and U. Rattanasak (2009). Influence of fineness of Rice Husk Ash and Additives on the Properties of Light Weight Aggregates, Construction and Building Materials, 88: 158-162.

Chopra, D.; R. Siddique and M. Kunal (2015). Strength, Permeability and Microstructure of Self Compacting Concrete Containing Rice Husk Ash. Biosystems Engineering, 130: $72-80$.

Chowdhury, S.; A. Maniar and O. M. Suganya (2015). Strength Development in Concrete with Wood Ash Blended Cement and Use of Soft Computing Models to Predict Strength Parameters". Journal of Advanced Research, 6: 907-913.

Coelho, V. A.; C. C. Guimarães, G. G. Doutto and P. P. Pedra (2019). Evaluation of mortar properties obtained through partial substitution of Portland cement by ashes of oil palm empty fruit bunch. Cerâmica 65, 359-36. Available on line at: http://dx.doi.org/10.1590/0366-69132019653752575. Assessed September 23. 2020.

Dabai, M. U.; C. Muhammad, B. U. Bagudo and A. Musa (2009). Studies on the Effect of Rice Husk Ash as Cement Admixture. Nigerian Journal of Basic and Applied Science, 17(2): 252-256.

Da Silva, F.G.; B. L. Jefferson, M. Liborio and P. Helene (2008). Improvement of Physical and Chemical Properties of Concrete with Brazilian Silica Rice Husk (SRH). Revista Ingeniería de Construcción, 23(1), 18-25.

Day, R. L. (1990). Pozzolans for Use in Low-Cost Housing - A State of the Art Report Prepared for the 
International Development Research Centre, Ottawa Canada. International Research Development Centre, Canada.

Ecosmart (2008). Environmental Impact - Cement production and the $\mathrm{CO}_{2}$ challenge. Available on line at: http://www.ecosmartconcrete.com/enviro_cement.cfm.

Assessed September 21, 2020.

Elinwa, A. U, and Mahmood, A. M. (2002). Ash from timber waste as cement replacement material. Cement Concrete Composites, 24: 219-22.

Elinwa, A. U, and Ejeh, S. P. (2004). Effects of incorporation of sawdust incineration fly ash in cement pastes and mortars. Journal of Asian Architecture Building Engineering, 3(1): 1-7.

Ettu, L. O.; M. S. W. Mbajiorgu, F. C. Njoku, C. A. Ajoku and K. C. Nwachukwu (2013). Strength variation of OPC-Saw dust ash composites with percentage saw dust ash. Civil and Environmental Research, 3(9): 53 - 58.

Ettu, L. O.; J. C. Ezeh, U. C. Anya, K. C. Nwachukwu and K. O. Njoku (2013). Strength of ternary blended cement concrete containing Afikpo rice husk ash and sawdust ash. International Journal of Engineering Science Invention, 2(4): $38-42$.

Falade, F.; E. Ikponmwosa and A. Arogundade (2011). Some Investigations into some Structural Properties of Foamed Aerated Concrete. Journal of Engineering Research, 16(1): $67-81$.

Fapohunda, C. A. and Shittu, A. (2017). Some Latter Ages Structural Characteristics of Concrete Containing Empty Palm Oil Fruit Brunch Ash (EPO-FBA) as Partial Replacement of Ordinary Portland Cement. FUOYE Journal of Engineering and Technology, 2(1): $82-86$.

Fapohunda, C.; B. Akinbile and A. Oyelade (2018). A Review of the Properties, Structural Characteristics and Application Potentials of Concrete Containing Wood Waste as Partial Replacement of one of its Constituent Material. YBL Journal of Built Environment, 6(1): $63-85$.

Fapohunda, C. A. and Oluwasegunota, O. B. (2019). Evaluation of Structural Performance of Concrete with OPC fraction Partly Replaced by Empty Palm Oil Brunch Ash (EPO-FBA). FUW Trends in Science \& Technology Journal, 4(1): $202-208$.

Fapohunda, C. A. (2019). Limit State Design of Reinforced Concrete Structural Elements.

Available on line at:

http://repository.fuoye.edu.ng/bitstream/123456789/1463/3/L imit\%20State\%20Design $\% 20$ of $\% 20$ Reinforced $\% 20$ Concrete $\%$ 20Structural\%20Elements\%20by\%20C.\%20A.\%20Fapohu nda.pdf. Assessed December 21, 2020.

FINELIB (2009). Rice Cultivation in Nigeria with main Producing States. Available on line at: http://finelib/about/nigeria. Asessed September 30, 2020.

Foong, K. Y.; U. J. Alengaram, M. Z. Jumaat and K. H. Mo (2015). Enhancement of the mechanical properties of lightweight oil palm shell concrete using rice husk ash and manufactured sand. Journal of Zhejiang University-SCIENCE A (Applied Physics \& Engineering), 16(1): $59-69$.
Gambhir, M. L. (2013). Concrete Technology - Theory and Practice. McGraw Hill Education Private Limited, New Delhi, India.

Ganesan, K.; K. Rajagopal and K. Thangavel (2008). Rice Husk Ash Blended Cement: Assessment of Optimal Level of Replacement for Strength and Permeability Properties of Concrete. Construction and Building Materials, 22(8): 1675-1683.

Ghorpade, V. G. (2012). Effect of wood waste ash on the strength characteristics of concrete. Nature Environment and Pollution Technology, 11(1): $121-124$.

Hasparyk, N. P.; P. J. M. Monteiro and H. Carasek (2000). Effect of silica fume and rice husk ash on alkali-silica reaction. Materials Journal, 97(4): 486-492.

Hwang, C. L. and Chandra, S. (2016). The Use of Rice Husk Ash in Concrete. Available on line at: https://3cl1105uvd.files.wordpress.com/2013/06/bookbysatish-chandra-220504.pdf. Assessed December 21, 2020.

Joel, M. (2010). A Review of Partial Replacement of Cement with Some Agro Wastes. Nigerian Journal of Technology, 29(2): $12-20$.

Ikponmwosa, E. E. and Olonade (2017). Shrinkage Characteristics of Cassava Peel Ash Concrete. The Pacific Journal of Science and Technology, 18(2): 23 - 32.

IRRI (2005). Rough Rice Production by Country and Geographical Region 1961-2004. International Rice Research Institute, Rome: FAOSTAT Database.

Karim, M. R.; M. F. M. Zain, M. Jamil and F. C. Lai (2013). Fabrication of a non-cement composite binder by using slag, palm oil fuel ash and rice husk ash with sodium hydroxide as an activator. Construction and Building Materials, 49: 894902.

Kartini, K.; H. B. Mahmud and M. S. Hamidah (2010). Absorption and Permeability Performance of Selangor Rice Husk Ash Blended Grade 30 Concrete. Journal of Engineering Science and Technology, 5(1): $1-16$.

Ketkukah, T. S. and Ndububa, E. E. (2006). Groundnut Husk Ash (GHS) as a pozzolana material in mortar. International Journal of Science and Technology Research, 3(2): 209-214.

Khassaf, S. I.; A. T. Jasim and F. K. Mahdi (2014). The Properties of Concrete Containing Rice Husk Ash to Reduce the Seepage in Canals. International Journal of Scientific \& Technology Research, 3(4): 348 - 354.

Le, H. T.; S. T. Nguyen and H. Ludwig (2014). A Study on High Performance Fine-Grained Concrete Containing Rice Husk Ash. International Journal of Concrete Structures and Materials, 8(4): $301-307$.

Mahmud, H. B.; S. Bahri, Y. W. Yee and Y. Y. Yeap (2016). Effect of Rice Husk Ash on the Strength and Durability of High Strength Performance Concrete. World Academy of Science, Engineering and Technology, 10(3): 375 - 380.

Marthong, C. (2012). Effect of Rice Husk Ash (RHA) as Partial Replacement of Cement on Concrete Properties. International Journal of Engineering Research \& Technology, 1(6): $1-8$.

Marthong, C. (2013). Size Effect Study of Sawdust Ash-Concrete under Compressive Load. IOSR Journal of Mechanical and Civil Engineering, 1(5): 27 - 32 
Mehta, P. K., (2002). Greening of the concrete industry for sustainable development. Concrete. International, 24 (7): 23-28.

Mehta, P. K. (2009). Global concrete industry sustainability. Concrete International. 31(02): 45-48.

Naik., T. R.; R. N. Kraus and R. Siddique (2002). Demonstration of manufacturing technology for concrete and CLSM utilizing wood ash from Wisconsin, Wisconsin Department of Natural Resources (Madison, WI) for project \#1 -06 UWM report no. CBU-2002-30, Center for By-products Utilization, Department of Civil Engineering and Mechanics, University of Wisconsin-Milwaukee.

Naik, T. R, and Kraus, R. N. (2003). A new source of pozzolanic materials. Concrete International, $55-62$.

Naik, T. R. and Moriconi, G. (2008). Environmentalfriendly durable concrete made with recycled materials for sustainable concrete construction. Retrieved from https://www4.uwm.edu/cbu/Coventry/Naiefd.pdf.

Nair, D. G.; A. Fraaij, A. A. K. Klaassen and A. P. M. Kentgens (2008). A Structural Investigation Relating to the Pozzolanic Activity of Rice Husk Ashes. Cement and Concrete Research, 38: 861-869.

Neville, A. M. (2011). Properties of concrete. Pearson Education Limited, Edinburgh, England.

Nguyen, V. T.; G. Ye, K. van Breugel, A. I. A. Fraaij and D. D. Bui (2011). The study of using rice husk ash to produce ultra-high performance concrete, Construction and Building Materials 25(4): 2030-2035.

Obilade, I. O. (2014). Use of Rice Husk Ash as Partial Replacement for Cement in Concrete. International Journal of Engineering and Applied Sciences, 5(4): 11 - 16.

Ochsendorf, J. A. (2005). Sustainable Engineering: The Future of Structural Design. Structures. American Society of Civil Engineers. Available on line at:

http://www.ascelibrary.org/. Assessed November 23, 2020.

Ogork, E. N. and Ayuba, S. (2014). Influence of sawdust ash (sda) as admixture in cement paste and concrete. IJISET - International Journal of Innovative Science, Engineering \& Technology, 1(10): 736 - 743.

Olonode, K. A.; A. M. Olajumoke, A. O. Omotosho and F. A. Oyekunle (2014). Effects of sulphuric acid on the compressive strength of blended cement cassava peel ash concrete. Construction Materials and Structures, 764 - 771.

Olutoge, F. A.; H. A. Quadri and O. S. Olafusi (2012). Investigation of the Strength Properties of Palm Kernel Shell Ash in Concrete. Engineering, Technology\& Applied Science Research, 2(6): 315 - 319.

Oyekan, G. L. and Kamiyo, O. M. (2011). A study on the engineering properties of sandcrete blocks produced with rice husk ash blended cement. Journal of Engineering and Technology Research, 3(3), 88-98.

Oyetola, E. B. and Abdullahi, M. (2004). The Use of Rice Husk Ash in Low-Cost Sandcrete Block Production. Leonardo Electronic J. Practices Technol., 8: 58-70.

Raheem, A. A.; B. S. Olasunkanmi and C. S. Folorunsho (2012). Saw Dust Ash as Partial Replacement for Cement in Concrete. Organization, technology and management in construction - an international journal, 4(2):474-480.
Rajamma, R.; R. J. Ball, L. A. C. Tarelho, G. C. Allen, J. A. Labrincha and V. M. Ferreira (2009). Characteristics and use of biomass fly ash in cement-based materials. Journal of Hazard Materials, 172: 1049-60.

Ramos, T.; A. M. Matos, and. J. Sousa-Coutinho. (2013). Mortar with wood waste ash: Mechanical strength carbonation resistance and ASR expansion. Construction and Building Materials, 49: 343-351.

Rashid, M. H.; M. K. A. Molla and T. U. Ahmed (2010). Durability of Mortar in Presence of Rice Husk Ash. World Academy of Science, Engineering and Technology 43: $736-739$.

Rashid, M. H. (2016). Strength Behavior of Cement Mortar Assimilating Rice Husk Ash. International Journal of Advances in Agricultural \& Environmental Engineering, 3(2): 288 - 293.

Sakr, K. (2006). Effects of Silica Fume and Rice Husk Ash on the Properties of Heavy Weight Concrete. Journal of Materials in Civil Engineering, 18 (3): 367-376.

Salau, M. S.; E. E. Ikponmwosa and K. A. Olonade (2012). Structural Strength Characteristics of Cement-Cassava Peel Ash Blended Concrete. Civil and Environmental Research, 2(10): 68 - 77.

Shafigh, P.; H. B. Mahmud, M. Z. Jumaat, and M. Zargar (2014). Agricultural wastes as aggregate in concrete mixtures - a review. Construction and. Building Materials, 53: 110-117.

Shatat, M. R. (2014). Hydration behaviour and mechanical properties of blended cement containing various amounts of rice husk ash in presence of metakaolin. Arabian Journal of Chemistry, http://dx.doi.org/10.1016/j.arabjc.2013.12.006

Subbaramaiah, G. (2016) Strength and durability studies on wood waste ash structural grade concrete. A PhD Thesis submitted to Jawaharlal Nehru Technological University Anantapur,

Sudendro, B. (2014). Toward green concrete for better sustainable environment. In: 2nd International Conference on Sustainable Civil Engineering Structures and Construction Materials, Procedia Engineering 95: 305-320.

Swaminathen, A. N. and Ravi, S. B. (2016). Use of Rice Husk Ash and Metakaolin as Pozzolonas for Concrete: A Review. International Journal of Applied Engineering Research, 11(1): 656 -664.

Talsania, S.; J. Pitroda and C. M. Vyas (2015). Effect of Rice Husk Ash on Properties of Pervious Concrete. International Journal of Advanced Engineering Research and Studies, 4(2): $296-299$.

Tangchirapat, W.; C. Jaturapitakkul and P. Chindaprasirt (2009). Use of Palm Oil Fuel Ash as a Supplementary Cementitious Material for Producing HighStrength Concrete. Construction and Building Materials, 23(7): 2641-2646.

Udoeyo, F. F.; H. Inyang, D. T. Young and E. E. Oparadu (2006). Potential of wood ash waste as an additive in concrete. Journal of Materials in Civil Engineering 18(4): 605-11. 
Wang, S.; E. Llamazos, L. Baxter and F. Fonseca. (2008). Durability of biomass fly ash concrete: freezing and thawing and rapid chloride permeability tests. Fuel, 87: 35964.
Yerramala, A. (2014). Properties of concrete with eggshell powder as cement replacement. Indian Concrete Journal, 94 - 102. 